CENDEKIA, Vol. 9, No. 2, Oktober 2015

p ISSN: 1978 2098; e ISSN: 2407 8557; Web: cendekia.pusatbahasa.or.id

Pusat Kajian Bahasa dan Budaya, Surakarta, Indonesia

Utomo H. Fajar, Wardhani, S. Indah \& Asrori, RA Mohammad. 2015. Komunikasi Matematika

Berdasarkan Teori van Hiele pada Mata Kuliah Geometri Ditinjau dari Gaya Belajar

Mahasiswa Program Studi Pendidikan Matermatika. Cendekia, 9(2): 159 170.

\title{
KOMUNIKASI MATEMATIKA BERDASARKAN TEORI \\ VAN HIELE PADA MATA KULIAH GEOMETRI DITINJAU DARI GAYA BELAJAR MAHASISWA PROGRAM STUDI PENDIDIKAN MATEMATIKA
}

\author{
Fajar Hendro Utomo, Indah Setyo Wardhani, \\ Mohammad Abdul Roziq Asrori \\ STKIP PGRI Tulungagung \\ Email: indahsetyowardhani@yahoo.co.id
}

\begin{abstract}
This objective of this study is to describe competency of mathematic communication based on Van Hiele theory on geometry course viewed from visual and kinesthetic learning styles. The study was conducted in STKIP PGRI Tulungagung in November 2013 to August 2014, assigning 45 students as sample. The study revealed that: First, auditory learning style was achieved by: Level $1=0$, Level $2=2$, Level $3=9$, Level $4=4$, and Level $5=0$, averaging at Level 3 . This means that students do not understand when they construct definition, argument, role, formal deduction they worked; Second, kinesthetic learning style was achieved by: Level $1=0$, Level $2=6$, Level $3=10$, Level $4=2$, and Level $5=0$, averaging at Level 3. This means that students do not understand on the work as done through auditory learning style.
\end{abstract}

Key-words: mathematic communication, learning style.

Perkembangan teknologi di dekade terakhir ini berjalan dengan sangat cepat dan pesat. Berbagai kemudahan bisa diperoleh oleh masyarakat melalui fasilitas teknologi. Salah satu fasilitas teknologi tersebut adalah internet. Dengan internet, kita dapat mengakses segala macam informasi. Dengan kebebasan mengkases segala macam informasi tersebut akan memunculkan kompetisi bagi generasi muda mendatang. Kompetisi akan semakin kuat untuk bisa bertahan menghadapi tantangan dunia. Hanya orang yang mampu beradaptasi secara cepat yang mampu menghadapi tantangan dunia. Orang yang mampu beradaptasi secara cepat adalah orang yang komunikatif dalam berkomunikasi.

Komunikasi merupakan suatu aktivitas penyampaian informasi (pesan, ide, gagasan) dari satu pihak kepada pihak lain. Aktivitas komunikasi sebagai aktivitas sosial (talking) dan sebagai alat bantu berfikir (writing) belakangan ini direkomendasikan para pakar agar terus ditumbuhkembangkan dikalangan pebelajar. Terutama dalam matematika, aktivitas komunikasi perlu ditumbuhkembangkan. Matematika dipandang sebagai suatu ilmu yang terstruktur dan terpadu, ilmu tentang pola dan hubungan, dan ilmu tentang cara berfikir serta memahami dunia sekitar dan matematika juga merupakan ilmu yang deduktif, bahasa simbol dan bahasa numerik. Sejalan dengan perkembangan teknologi, ada dua alasan penting 
mengapa komunikasi dalam matematika perlu difokuskan menurut menurut Baroody (1993) yaitu: (1) mathematics as language; matematika tidak hanya sekedar alat bantuberpikir (a tool to aid thinking), alat untuk menemukan pola, ataumenyelesaikan masalah namun matematika juga "an invaluable tool forcommunicating a variety of ideas clearly, precisely, and succintly," dan (2) mathematics learning as social activity; sebagai aktivitas sosial, dalampembelajaran matematika, interaksi antar siswa, seperti juga komunikasi guru siswa merupakan bagian penting untuk "nurturing children's mathematicalpotential". Bahkan menurut Cai (1996) "communication is considered as themeans by which teachers and students can share the process of learning, understanding, dan doing mathematics."

Greenes dan Schulman (1996:15-160) menyatakan bahwa komunikasi matematis meliputi kemampuan dalam mengekspresikan ide dengan berbicara, menulis, memperagakan dan melukiskannya secara visual dengan berbagai cara yang berbeda; memahami, menginterpretasikan dan mengevaluasi ide yang dikemukakannya dalam bentuk tulisan atau visual lainnya; mengkonstruksi, menginterpretasi dan menghubungkan berbagai representasi dari ide-ide dan hubungan-hubungan; mengamati, membuat konjektur, mengajukan pertanyaan, mengumpulkan dan mengevaluasi informasi; menghasilkan dan menghadirkan argumen yang jelas.Kemampuan komunikasi dalam pembelajaran matematika sangat perlu untuk diperhatikan. Hal ini disebabkan karena dengan komunikasi matematika akan dapat mengorganisasi dan mengkonsolidasi berpikir matematis baik secara lisan maupun tulisan. Apabila seseorang mempunyai kemampuan komunikasi tentunya akan membawa kepada pemahaman matematika yang mendalam tentang konsep matematika yang dipelajari.

Matematika menurut Bell (dalam Zulkardi, 2004: 1) secara garis besar dibagi ke dalam 4 cabang, yaitu aritmetika, aljabar, geometri, dan analisis. Geometri yang merupakan satu cabang matematika mempunyai peran yang cukup penting untuk dipelajari. Usikin (Kahfi, 1999) mengemukakan ada 3 alasan mempelajari geometri menurut, yaitu: (1) geometri dapat mengaitkan matematika dengan bentuk fisik dunia nyata, (2) geometri memungkinkan ide-ide dari bidang matematika yang lain untuk digambar, dan (3) geometri dapat memberikan contoh yang tidak tunggal tentang sistem matematika. Sejalan dengan pendapat Usikin, Budiarto (2000: 439) menyatakan bahwa tujuan pembelajaran geometri adalah untuk mengembangkan kemampuan berfikir logis, mengembangkan intuisi ke ruangan, menanamkan pengetahuan untuk menunjang materi yang lain, dan dapat membaca serta menginterpretasikan argumenargumen matematika. Dengan mempelajari geometri dapat menumbuhkan kemampuan berfikir logis, mengembangkan kemampuan memecahkan masalah dan pemberian alasan serta dapat mendukung banyak topik lain dalam matematika. Dari sini peneliti tertarik untuk melihat gambaran secara umum terkait kemampuan komunikasi matematika pada mata kuliah geometri.

Gambaran dari kemampuan komunikasi matematika dalam penelitian ini dikaitkan dengan teoriVan Hiele. Teori Van Hiele merupakan tolak ukur dalam melihat kemampuan komunikasi matematika dalam geometri.Dalam teori Van Hiele, tingkat berfikir geometri dapat dilalui secara berurutan melalui 5 tingkat, yaitu; tingkat 1 (visualisasi), tingkat 2 (analysis), tingkat 3 (informal deduction), tingkat 4 (Deduction), tingkat 5 (Rigor). Masingmasing tingkat pemikiran mempunyai bahasa dan interpretasi sendiri terhadap istilah yang 
sama.Kondisi ini menjadi peluang mahasiswa dalam menampakkan komunikasi matematiknya. Menurut D’Augustine dan Smith (1992: 277), Crowley (1987:5), menyatakan bahwa kemajuan tingkat berpikir geometri dari satu tingkatan ke tingkatan berikutnya melibatkan lima tahapan atau sebagai hasil dari pengajaran yang diorganisir ke lima tahap pembelajaran. Kemajuan dari satu tingkat ke tingkat berikutnya lebih bergantung pada pengalaman pembelajaran ketimbang pada usia atau kematangan. Sejumlah pengalaman dapat mempermudah (atau menghambat) kemajuan dalam satu tingkat atau ke satu tingkat yang lebih tinggi.Dari sini peneliti akanmelihat gambaran komunikasi matematika berdasarkan tingkatan yang ada dalam teori Van Hiele.

STKIP PGRI Tulungagung merupakan perguruan tinggi swasta yang berada di wilayah Tulungagung Jawa Timur. Kondisi mahasiswa STKIP PGRI Tulungagung berasal dari input yang beragam, mulai dari SMA, SMK, Kejar Paket C dan transfer.62\% mahasiswa sudah bekerja dan sisanya atau $38 \%$ belum bekerja.Pekerjaan yang ditekuni beragam, dari wiraswasta, guru tidak tetap, pegawai bank, dan pekerja pabrik. Data tersebut terekam dari data kemahasiswaan STKIP PGRI Tulungagung pada tahun 2012 seagaimana tersaji dalam tabel 1 berikut.

Tabel 1, Kondisi Mahasiswa STKIP PGRI Tulungagung

\begin{tabular}{|lc}
\hline \multicolumn{1}{c}{ Input Mahasiswa } & Prosentase \\
\hline SMA & $55 \%$ \\
\hline SMK & $35 \%$ \\
\hline Paket C & $1 \%$ \\
\hline Transfer & $9 \%$ \\
\hline Mahasiswa yang sudah bekerja & $62 \%$ \\
\hline Mahasiswa yang belum bekerja & $38 \%$ \\
\hline
\end{tabular}

Dari input yang beragam tersebut, penulis awalnya memandang bahwa gaya mahasiswa dalam belajar akan mengalami keberagaman. Gaya mahasiswa dalam belajar didasarkan pada kemudahan mereka dalam menyerap dan memproses informasi.

Menurut DePorter dan Hernacki (1999), gaya belajar adalah kombinasi dari menyerap, mengatur, dan mengolah informasi. Secara umum, gaya belajar dikelompokkan berdasarkan kemudahan dalam menyerap informasi (perceptual modality), cara memproses informasi (informationprocessing), dan karakteristik dasar kepribadian (personality pattern).

Pengelompokan berdasarkanperceptual modality didasarkan pada reaksi individu terhadap lingkungan fisik dan cara individu menyerap data secara lebih efisien. Pengelompokan berdasarkan information processing didasarkan pada cara individu merasa, memikirkan, memecahkan masalah, dan mengingat informasi. Sedangkan pengelompokan berdasarkan personality pattern didasarkan pada perhatian, emosi, dan nilai-nilai yang dimiliki oleh individu. DePorter dan Hernacki (1999) mengemukakan tiga jenis gayabelajar berdasarkan modalitas yang digunakan individu dalam memproses informasi (perceptual modality). Ketiga gaya belajar tersebut adalah gaya belajar visual, auditorial, dan kinestetik.

Orang yang memiliki gaya belajar visual, belajar dengan menitikberatkan ketajaman 
penglihatan. Artinya, bukti-bukti konkret harus diperlihatkan terlebih dahulu agar mereka paham. Orang yang memiliki gaya belajar auditory, belajar dengan mengandalkan pendengaran untuk bisa memahami sekaligus mengingatnya. Karakteristik model belajar ini benar-benar menempatkan pendengaran sebagai alat utama untuk menyerap informasi atau pengetahuan.Artinya, untuk bisa mengingat dan memahami informasi tertentu, yang bersangkutan haruslah mendengarnya lebih dulu. Orang yang memiliki gaya belajar kinestetik, mengharuskan individu yang bersangkutanmenyentuh sesuatu yang memberikan informasi tertentu agar ia bisa mengingatnya.

Pada bulan November, penulis mengadakan penelitian awal yaitu melihat karakteristik gaya belajar dari mahasiswa matematika STKIP PGRI Tulungagung. Dari penelitian awal yang dilakukan melalui sebaran angket gaya belajar, didapatkan data keberagaman gaya belajar mahasiswa. Dari 45 mahasiswa dalam 1 kelas, didapatkan 12 mahasiswa dengan gaya belajar visual, 15 mahasiswa dengan gaya belajar auditorial dan sisanya kinestatik. Lebih lanjut, hasil karakteristik gaya belajar tersaji dalam tabel 2 sebagai berikut.

Tabel 2. Karakteristik Gaya Belajar Mahasiswa

\begin{tabular}{lc}
\hline \multicolumn{1}{c}{ Gaya Belajar } & Jumlah Mahasiswa \\
\hline Gaya Belajar Visual & 12 \\
\hline Gaya Belajar Auditorial & 15 \\
\hline Gaya Belajar Kinestatik & 18 \\
\hline TOTAL & 45 \\
\hline
\end{tabular}

(Sumber dari analisis peneliti)

Dari uraian diatas, peneliti tertarik untuk melihat gambaran secara umum terkait kemampuan komunikasi matematika berdasarkan tahap berfikir teori Van Hiele pada mata kuliah Geometri ditinjau dari gaya belajar mahasiswa yang beragam.

\section{METODE}

Penelitian ini menggunakan design deskriptif dengan pendekatan kualitatif. Penelitian dilakukan pada 45 mahasiswa matematika STKIP PGRI Tulungagung semester 2 tahun akademik 2013/2014. Data penelitian ini mencakup: hasil observasi gaya belajar mahasiswa, hasil angket gaya belajar, skor tes, and hasil wawancara. Data dianalisis menggunakan analisis taksonomi model Miles dan Hubermen (2004).

\section{HASIL DAN BAHASAN}

\section{Hasil Angket}

Angket gaya belajar ini diberikan pada mahasiswa dengan tujuan untuk menggolongkan berdasarkan katagorisasi dalam jenis gaya belajar yang meliputi auditorial, visual dan kinestetik. Berdasarkan hasil angket gaya belajar menunjukkan bahwa jawaban mahasiswa terhadap pengisian angket bermacam-macam. Jawaban tersebut sesuai dengan kenyataan yang ada pada diri mahasiswa-mahasiswa tersebut, sehingga dapat diketahui bahwa 
mahasiswa mempunyai gaya belajar yang berbeda-beda. Dari 45 mahasiswa dalam 1 kelas, didapatkan 12 mahasiswa dengan gaya belajar visual, 15 mahasiswa dengan gaya belajar auditory dan 18 mahasiswa dengan gaya belajar kinestatik. Dengan keberagaman gaya belajar tersebut, penelitian ini akan melihat gambaran secara umum terkait kemampuan komunikasi mahasiswa pada mata kuliah geometri. Dalam teori Van Hiele, tingkat berfikir geometri yang dijadikan sebagai tolok ukur kemampuan komunikasi matematika dapat dilalui secara berurutan melalui 5 tingkat, yaitu; tingkat 1 (visualisasi), tingkat 2 (analysis), tingkat 3 (informal deduction), tingkat 4 (Deduction), tingkat 5 (Rigor). Tabel 3.

Tabel 3. Inisial Mahasiswa Berdasarkan Gaya Belajar

\begin{tabular}{|l|c|c|c|}
\hline No & Auditorial & Visual & Kinestatik \\
\hline 1 & ANH & FDK & DFP \\
\hline 2 & ALG & INS & DPS \\
\hline 3 & CAP & IHM & HIS \\
\hline 4 & DOV & MAS & LSR \\
\hline 5 & IZA & NTL & SNA \\
\hline 6 & KRM & RNS & BAY \\
\hline 7 & RDI & SSD & SAT \\
\hline 8 & RHY & WDK & WIS \\
\hline 9 & RHS & YFF & YOG \\
\hline 10 & YKS & YDA & SIL \\
\hline 11 & RKM & & BOB \\
\hline 12 & ISW & & PRI \\
\hline 13 & ADS & & SAS \\
\hline 14 & DRP & & BRO \\
\hline 15 & MAR & NIL \\
\hline 16 & & & \\
\hline 17 & & & \\
\hline 18 & & & \\
\hline
\end{tabular}

\section{Hasil Observasi}

Data observasi aktivitas mahasiswa berdasarkan gaya belajar auditorial, visual dan kinestetik pada pembelajaran materi I dan dan pembelajaran materi 2 pada mata kuliah Geometri dihitung berdasarkan kriteria berikut.

$$
\begin{aligned}
& 75 \% \leq \mathrm{NR} \leq 100 \%: \quad 25 \% \leq \mathrm{NR}<50 \\
& \text { Sangat Baik \%: Cukup } \\
& 50 \% \leq \mathrm{NR}<75 \%: \quad 0 \% \leq \mathrm{NR}<25 \\
& \text { Baik \%: Kurang }
\end{aligned}
$$


CENDEKIA, Vol. 9, No. 2, Oktober 2015

p ISSN: 1978 2098; e ISSN: 2407 8557; Web: cendekia.pusatbahasa.or.id

Pusat Kajian Bahasa dan Budaya, Surakarta, Indonesia

Utomo H. Fajar, Wardhani, S. Indah \& Asrori, RA Mohammad. 2015. Komunikasi Matematika

Berdasarkan Teori van Hiele pada Mata Kuliah Geometri Ditinjau dari Gaya Belajar

Mahasiswa Program Studi Pendidikan Matermatika. Cendekia, 9(2): 159 170.

\section{Hasil Observasi Gaya BelajarAuditorial}

Hasil observasi mahasiswa berdasarkan gaya belajar auditorial selama proses pembelajar menunjukkan bahwa aktivitas mahasiswa sangat baik, dengan persentase $85,71 \%$. (Tabel 4).

Tabel 4. Gaya Belajar Auditorial pada Materi I dan Materi II

\begin{tabular}{|c|c|c|c|c|c|}
\hline No & Kriteria & Materi I & Skor & Materi II & Skor \\
\hline 1 & $\begin{array}{l}\text { Perhatian mhs thd } \\
\text { penjelasan dosen }\end{array}$ & $\begin{array}{l}\text { Memperhatikan, } \\
\text { menyimak }\end{array}$ & 2 & $\begin{array}{l}\text { Memperhatikan, } \\
\text { menyimak }\end{array}$ & 3 \\
\hline 2 & $\begin{array}{ll}\text { Aktifitas } & \text { dalam } \\
\text { kelompok } & \end{array}$ & $\begin{array}{l}\text { Dapat bekerja } \\
\text { sama }\end{array}$ & 3 & Dapat bekerja sama & 4 \\
\hline 3 & $\begin{array}{l}\text { Kemampuan } \\
\text { mengenukakan } \\
\text { pendapat }\end{array}$ & $\begin{array}{l}\text { Mengemukakan } \\
\text { ide, menjawab } \\
\text { pertanyaan teman }\end{array}$ & 3 & $\begin{array}{l}\text { Mengemukakan ide, } \\
\text { menjawab pertanyaan } \\
\text { teman }\end{array}$ & 4 \\
\hline 4 & $\begin{array}{l}\text { Kemampuan } \\
\text { memanfaatkan } \\
\text { waktu }\end{array}$ & $\begin{array}{l}\text { Responsif, runtut, } \\
\text { mudah dipahami, } \\
\text { tepat waktu }\end{array}$ & 4 & $\begin{array}{l}\text { Responsif, runtut, } \\
\text { mudah dipahami, } \\
\text { tepat waktu }\end{array}$ & 4 \\
\hline 5 & $\begin{array}{l}\text { Kemampuan } \\
\text { membangun ide }\end{array}$ & $\begin{array}{l}\text { Memahami materi, } \\
\text { mengorganisasi ide }\end{array}$ & 3 & $\begin{array}{l}\text { Memahami materi, } \\
\text { mengorganisasi ide }\end{array}$ & 4 \\
\hline 6 & $\begin{array}{l}\text { Kemampuan } \\
\text { menarik simpulan }\end{array}$ & $\begin{array}{l}\text { Simpulan benar, } \\
\text { logis, sesuai tujuan } \\
\text { pembelajaran }\end{array}$ & 4 & $\begin{array}{ll}\text { Simpulan } & \text { benar, } \\
\text { logis, sesuai } & \text { tujuan } \\
\text { pembelajaran } & \\
\end{array}$ & 3 \\
\hline \multirow[t]{3}{*}{7} & $\begin{array}{l}\text { Kemampuan } \\
\text { mengerjakan } \\
\text { latihan praktik }\end{array}$ & $\begin{array}{l}\text { Jawaban benar, } \\
\text { runtut, rapi }\end{array}$ & 3 & $\begin{array}{l}\text { Jawaban benar, } \\
\text { runtut, rapi }\end{array}$ & 4 \\
\hline & & & 22 & & 26 \\
\hline & & & 78.57 & & 92.86 \\
\hline
\end{tabular}

\section{Observasi Aktivitas Mahasiswa Berdasarkan Gaya Belajar Visual}

Hasil observasi mahasiswa berdasarkan gaya belajar visual selama proses pembelajar menunjukkan bahwa aktivitas mahasiswa sangat baik, yang ditunjukkan pada prosentase keberhasilan dengan rata-rata prosentase keberhasilan sebesar 91,07\%. (Periksa Tabel 5).

\section{Observasi Aktivitas Mahasiswa Berdasarkan Gaya Belajar Kinestetik}

Hasil observasi mahasiswa berdasarkan gaya belajar kinestetik selama proses pembelajar menunjukkan bahwa aktivitas mahasiswa pada pertemuan pertama baik, pada pertemuan kedua sangat baik dan rata-rata aktivitas mahasiswa sangat baik, yang ditunjukkan pada prosentase keberhasilan pada pertemuan pertama sebesar 71,43\% dan pada pertemuan kedua sebesar $85,71 \%$ dengan rata-rata prosentase keberhasilan sebesar $78,57 \%$. Pariksa Tabel 6.

Jadi dapat disimpulkan bahwa hasil observasi aktivitas mahasiswa berdasarkan gaya belajar (auditorial, visual dan kinestetik) menunjukkan bahwa dalam proses pembelajaran mata kuliah geometri aktivitas mahasiswa sangat baik dengan rata-rata prosentase keberhasilan pada pertemuan I dan pertemuan II yaitu mahasiswa berdasarkan gaya belajar auditorial 85,71\%, mahasiswa berdasarkan gaya belajar visual 91,07\% dan mahasiswa berdasarkan gaya belajar kinestetik 78,57\%. 
CENDEKIA, Vol. 9, No. 2, Oktober 2015

p ISSN: 1978 2098; e ISSN: 2407 8557; Web: cendekia.pusatbahasa.or.id

Pusat Kajian Bahasa dan Budaya, Surakarta, Indonesia

Utomo H. Fajar, Wardhani, S. Indah \& Asrori, RA Mohammad. 2015. Komunikasi Matematika

Berdasarkan Teori van Hiele pada Mata Kuliah Geometri Ditinjau dari Gaya Belajar

Mahasiswa Program Studi Pendidikan Matermatika. Cendekia, 9(2): 159 170.

Tabel 5. Gaya Belajar Visual pada Materi I dan Materi II

\begin{tabular}{|c|c|c|c|c|c|}
\hline No & Kriteria & Materi I & Skor & Materi II & Skor \\
\hline 1 & $\begin{array}{l}\text { Perhatian mhs thd } \\
\text { penjelasan dosen }\end{array}$ & $\begin{array}{l}\text { Memperhatikan, } \\
\text { menyimak }\end{array}$ & 2 & $\begin{array}{l}\text { Memperhatikan, } \\
\text { menyimak }\end{array}$ & 4 \\
\hline 2 & $\begin{array}{ll}\text { Aktifitas } & \text { dalam } \\
\text { kelompok } & \end{array}$ & $\begin{array}{l}\text { Dapat bekerja } \\
\text { sama }\end{array}$ & 3 & Dapat bekerja sama & 3 \\
\hline 3 & $\begin{array}{l}\text { Kemampuan } \\
\text { mengenukakan } \\
\text { pendapat }\end{array}$ & $\begin{array}{l}\text { Mengemukakan } \\
\text { ide, menjawab } \\
\text { pertanyaan teman }\end{array}$ & 3 & $\begin{array}{l}\text { Mengemukakan ide, } \\
\text { menjawab pertanyaan } \\
\text { teman }\end{array}$ & 4 \\
\hline 4 & $\begin{array}{l}\text { Kemampuan } \\
\text { memanfaatkan } \\
\text { waktu }\end{array}$ & $\begin{array}{l}\text { Responsif, runtut, } \\
\text { mudah dipahami, } \\
\text { tepat waktu }\end{array}$ & 3 & $\begin{array}{l}\text { Responsif, runtut, } \\
\text { mudah dipahami, } \\
\text { tepat waktu }\end{array}$ & 4 \\
\hline 5 & $\begin{array}{l}\text { Kemampuan } \\
\text { membangun ide }\end{array}$ & $\begin{array}{l}\text { Memahami materi, } \\
\text { mengorganisasi ide }\end{array}$ & 4 & $\begin{array}{l}\text { Memahami materi, } \\
\text { mengorganisasi ide }\end{array}$ & 4 \\
\hline 6 & $\begin{array}{l}\text { Kemampuan } \\
\text { menarik simpulan }\end{array}$ & $\begin{array}{l}\text { Simpulan benar, } \\
\text { logis, sesuai tujuan } \\
\text { pembelajaran }\end{array}$ & 4 & $\begin{array}{l}\text { Simpulan benar, } \\
\text { logis, sesuai tujuan } \\
\text { pembelajaran }\end{array}$ & 4 \\
\hline \multirow[t]{3}{*}{7} & $\begin{array}{l}\text { Kemampuan } \\
\text { mengerjakan } \\
\text { latihan praktik }\end{array}$ & $\begin{array}{l}\text { Jawaban benar, } \\
\text { runtut, rapi }\end{array}$ & 4 & $\begin{array}{l}\text { Jawaban benar, } \\
\text { runtut, rapi }\end{array}$ & 4 \\
\hline & & & 24 & & 27 \\
\hline & & & 85.71 & & 96.42 \\
\hline
\end{tabular}

Tabel 6. Gaya Belajar Kinestetik pada Materi I dan Materi II

\begin{tabular}{|c|c|c|c|c|c|}
\hline No & Kriteria & Materi I & Skor & Materi II & Skor \\
\hline 1 & $\begin{array}{l}\text { Perhatian mhs thd } \\
\text { penjelasan dosen }\end{array}$ & $\begin{array}{l}\text { Memperhatikan, } \\
\text { menyimak }\end{array}$ & 2 & $\begin{array}{l}\text { Memperhatikan, } \\
\text { menyimak }\end{array}$ & 3 \\
\hline 2 & $\begin{array}{ll}\text { Aktifitas } & \text { dalam } \\
\text { kelompok } & \end{array}$ & $\begin{array}{l}\text { Dapat bekerja } \\
\text { sama }\end{array}$ & 3 & Dapat bekerja sama & 3 \\
\hline 3 & $\begin{array}{l}\text { Kemampuan } \\
\text { mengenukakan } \\
\text { pendapat }\end{array}$ & $\begin{array}{l}\text { Mengemukakan } \\
\text { ide, menjawab } \\
\text { pertanyaan teman }\end{array}$ & 3 & $\begin{array}{l}\text { Mengemukakan ide, } \\
\text { menjawab pertanyaan } \\
\text { teman }\end{array}$ & 4 \\
\hline 4 & $\begin{array}{l}\text { Kemampuan } \\
\text { memanfaatkan } \\
\text { waktu }\end{array}$ & $\begin{array}{l}\text { Responsif, runtut, } \\
\text { mudah dipahami, } \\
\text { tepat waktu }\end{array}$ & 2 & $\begin{array}{l}\text { Responsif, runtut, } \\
\text { mudah dipahami, } \\
\text { tepat waktu }\end{array}$ & 3 \\
\hline 5 & $\begin{array}{l}\text { Kemampuan } \\
\text { membangun ide }\end{array}$ & $\begin{array}{l}\text { Memahami materi, } \\
\text { mengorganisasi ide }\end{array}$ & 3 & $\begin{array}{l}\text { Memahami materi, } \\
\text { mengorganisasi ide }\end{array}$ & 3 \\
\hline 6 & $\begin{array}{l}\text { Kemampuan } \\
\text { menarik simpulan }\end{array}$ & $\begin{array}{l}\text { Simpulan benar, } \\
\text { logis, sesuai tujuan } \\
\text { pembelajaran }\end{array}$ & 4 & $\begin{array}{l}\text { Simpulan benar, } \\
\text { logis, sesuai tujuan } \\
\text { pembelajaran }\end{array}$ & 3 \\
\hline \multirow[t]{3}{*}{7} & $\begin{array}{l}\text { Kemampuan } \\
\text { mengerjakan } \\
\text { latihan praktik }\end{array}$ & $\begin{array}{l}\text { Jawaban benar, } \\
\text { runtut, rapi }\end{array}$ & 3 & $\begin{array}{l}\text { Jawaban benar, } \\
\text { runtut, rapi }\end{array}$ & 4 \\
\hline & & & 20 & & 24 \\
\hline & & & 71.45 & & 85.71 \\
\hline
\end{tabular}




\section{Hasil Tes}

Soal tes mata kuliah Geometri diberikan pada mahasiswa kelas C dengan jumlah mahasiswa 45 orang. Setiap mahasiswa mendapatkan soal yang sama yang artinya tidak ada perbedaan soal antara mahasiswa dengan klasifikasi gaya belajar visual, Audiotorial dan kinestatik. Berdasarkan hasil tes yang dilakukan setelah pembelajaran mata kuliah Geometri tersaji dalam tabel 7.

Tabel 7. Rekapitulasi Nilai Tes Kemampuan Komunikasi Matematika

\begin{tabular}{|l|l|l|l|l|}
\hline No & Kriteria Skor & Level & Jumlah Mhs & $\%$ \\
\hline 1 & $>90$ & 5 & - & 0 \\
\hline 2 & $79<$ Nilai $\leq 90$ & 4 & 8 & 17.7 \\
\hline 3 & $74<$ Nilai $\leq 79$ & 3 & 27 & 60 \\
\hline 4 & $50 \leq$ Nilai $\leq 74$ & 2 & 10 & 22.3 \\
\hline 5 & $<50$ Nilai & 1 & 0 & 0 \\
\hline
\end{tabular}

Rerata kemampuan komunikasi matematika ialah level 4, yaitu $8(17,7 \%)$, level 3 sebanyak 27 (60\%), level 2 ialah 10 (22,3\%). Jadi tingkat kemampuan komunikasi matematika mahasiswa ialah level 3 yang artinya ketika mahasiswa menciptakan definisi yang bermakna dan memberi argumen informal untuk membenarkan penalaran mereka, peran dan signifikansi dari deduksi formal tidak dipahami.

\section{Analisis Gaya Belajar Auditorial, Visual dan Kinestetik}

Hasil analisis jawaban mahasiswa menunjukkan bahwa jawaban mahasiswa yang ditemukan pada mata kuliah geometri berbeda pada setiap indikator. Kriteria level menunjukkan deskripsi berikut: level 1 (Visualisasi), level 2 (Analisis), level 2 (Abstraksi), level 4 (Deduksi) dan memenuhi level 5 (Ketat/rigor).

Dari hasil analisis jawaban mahasiswa berdasarkan gaya belajar auditorial: Level $1=$ 0, Level $2=2$, Level $3=3$, Level $4=4$, dan Level $5=0$.

Level 1 menunjukkan bahwa pembuatan keputusan bukan berdasarkan persepsi, melainkan menggunakan penalaran. Pengenalan gambar-gambar geometri tidak hanya pada penampilan luar.

Level 2 berarti mahasiswa yang mengalami kondisi dimana etika menggambarkan sebuah objek, sudah mencantumkan semua sifat yang diketahui, tetapi tidak melihat sifat mana yang perlu dan mana yang cukup untuk menggambarkan objek tersebut.

Level 3 artinya ketika mahasiswa menciptakan definisi yang bermakna dan memberi argumen informal untuk membenarkan penalaran mereka, peran dan signifikansi dari deduksi formal tidak dipahami.

Level 4 artinya dapat mengkonstruksi bukti, memahami peran aksioma dan definisi, dan mengetahui makna dari kondisi-kondisi yang perlu dan yang cukup.

Level 5 artinya tidak memahami aspek-aspek formal dari deduksi, seperti pembentukan dan pembandingan sistem-sistem matematika. Dapat memahami penggunaan 
bukti tak langsung dan bukti melalui kontra-positif, dan dapat memahami sistem-sistem nonEuclidean.

Jadi dapat disimpulkan bahwa tingkat kemampuan komunikasi matematika mahasiswa berdasarkan teori van hiele ditinjau dari gaya belajar auditorial lebih banyak masuk level 3 .

Berdasarkan gaya belajar visual diperoleh: Level $1=0$, Level $2=2$, Level $3=8$, Level $4=2$, dan Level $5=0$. Rerata berada pada level 3 untuk gaya audiotorial.

Gaya belajar auditorial menunjukkan hasil Level $1=0$, Level $2=6$, Level $3=10$, Level $4=2$, dan Level 5=0. Rerata pada level 3 .

Tabel 8. Rekap

\begin{tabular}{|l|l|l|l|l|}
\hline No & Level & Auditorial & Visual & Kinestatik \\
\hline 1 & Visualisasi (recognition) & - & - & - \\
\hline 2 & Analisis & 2 & 2 & 6 \\
\hline 3 & Abstraksi, deduction, ordering & 9 & 8 & 10 \\
\hline 4 & Deduksi & 4 & 2 & 2 \\
\hline 5 & Ketat/rigor & - & - & - \\
\hline & & 15 & 12 & 18 \\
\hline
\end{tabular}

Data di atas menunuukkan bahwa mahasiswa mayoritas memiliki gaya belajar auditorial level 3. Dengan gaya belajar yang berbeda-beda menunjukkan bahwa tingkat kemampuan komunikasi matematika mahasiswa tergolong baik.

\section{Wawancara}

Hasil wawancara menjelaskan bagaimana gaya auditorial, visual dan kinestetik dipersepsi oleh mahasiswa. Gaya belajar auditorial menyatakan senang terhadap mata kuliah geometri karena berguna dalam kehidupan sehari-hari, mereka tidak senang dengan perkuliahan yang dimulai dari soal, melainkan diarahkan pada permasalahan yang berkaitan dengan kehidupan sehari-hari.

Gaya belajar visual menyatakan senang terhadap mata kuliah geometri, tidak senang dengan dengan pembelajaran geometri yang dimulai dari soal, senang belajar geometri jika masalah yang diberikan sesuai dengan kehidupan sehari-hari.

Gaya belajar kinestetik menyatakan cukup senang terhadap mata kuliah geometri, pembelajaran geometri cukup berguna dalam kehidupan sehari-hari, senang dengan dengan mata kuliah geometri yang dimulai dari soal, tidak mengalami kesulitan untuk memahami mata kuliah geometri.

\section{BAHASAN}

Penelitian ini menegaskan sesuai dengan teori Potter ditegaskan bahwa gaya belajar ada tiga macam yaitu: auditorial, visual dan kinestetik. Mahasiswa berdasarkan gaya belajar auditorial umumnya memaksimalkan penggunaan indra pendengar (telinga) dalam proses penangkapan dan penyerapan informasi, mereka memperlihatkan ketertarikan yang lebih pada suara-suara dan kata-kata. Kemampuan mereka dalam berbicara lebih cepat dan juga cepat 
mengenal kata-kata baru serta senang bila dibacakan cerita-cerita. Mahasiswa berdasarkan gaya belajar visual disebut sebagai gaya belajar pengamatan, sehingga sangat mengandalkan indra penglihatan (mata) dalam proses pembelajaran seperti ketertarikan mahasiswa dengan warna, bentuk, dan gambar-gambar hidup. Sedangakan mahasiswa berdasarkan gaya belajar kinestetik biasanya disebut juga sebagai gaya belajar penggerak, karena mereka senantiasa menggunakan dan memanfaatkan anggota gerak tubuhnya dalam proses pembelajaran atau dalam usaha memahami sesuatu. Hal ini bisa dilihat sesuai hasil angket gaya belajar yang menunjukkan bahwa dari 45 mahasiswa memenuhi ketiga macam gaya belajar tersebut yaitu terdapat 15 mahasiswa berdasarkan gaya belajar auditorial, 12 mahasiswa berdasarkan gaya belajar visual, dan 18 mahasiswa berdasarkan gaya belajar kinestetik.

Pada penilaian kemampuan komunikasi matematika mahasiswa berdasarkan gaya belajar ini menggunakan teori Van hile. Dalam teori Van Hiele, tingkat berfikir geometri yang dijadikan sebagai tolak ukur kemampuan komunikasi matematika dapat dilalui secara berurutan melalui 5 tingkat, yaitu; tingkat 1 (visualisasi), tingkat 2 (analysis), tingkat 3 (informal deduction), tingkat 4 (Deduction), tingkat 5 (Rigor). Dalam penelitian ini, hasil tes mahasiswa level yang terpenuhi yaitu level 2 sampai dengan level 4. Mahasiswa berdasarkan gaya belajar auditorial dapat mencapai level 4 dan mayoritas dapat memenuhi level 3, mahasiswa berdasarkan gaya belajar visual mahasiswa dapat mencapai level 4 dan mayoritas dapat memenuhi level 3 dan mahasiswa berdasarkan gaya belajar kinestetik mahasiswa hanya dapat mencapai level 4 dan mayoritas dapat memenuhi level 3 pula. Jadi dapat disimpulkan bahwa dengan gaya belajar yang berbeda-beda menunjukkan bahwa tingkat kemampuan komunikasi matematika mahasiswa yang beragam.

Hasil observasi aktivitas mahasiswa berdasarkan gaya belajar (auditorial, visual dan kinestetik) menunjukkan bahwa dalam proses pembelajaran mata kuliah Geometri aktivitas mahasiswa sangat baik dengan rata-rata prosentase keberhasilan pada pembelajaran materi I dan pembelajaran materi II yaitu mahasiswa berdasarkan gaya belajar auditorial $85,71 \%$, mahasiswa berdasarkan gaya belajar visual $91,07 \%$ dan mahasiswa berdasarkan gaya belajar kinestetik 78,57\%.

\section{SIMPULAN} berikut:

Berdasarkan hasil pengolahan dan analisis data dapat diambil simpulan sebagai

1. Mahasiswa dengan gaya belajar auditorial lebih banyak masuk level 3 yang artinya ketika mahasiswa menciptakan definisi yang bermakna dan memberi argumen informal untuk membenarkan penalaran mereka, peran dan signifikansi dari deduksi formal tidak dipahami.

2. Mahasiswa dengan gaya belajar visual masuk level 3 yang artinya ketika mahasiswa menciptakan definisi yang bermakna dan memberi argumen informal untuk membenarkan penalaran mereka, peran dan signifikansi dari deduksi formal tidak dipahami.

3. Mahasiswa dengan gaya belajar kinestatik menunjukkan tingkat komunikasi matematika level 3 yang artinya ketika mahasiswa menciptakan definisi yang bermakna dan memberi 
argumen informal untuk membenarkan penalaran mereka, peran dan signifikansi dari deduksi formal tidak dipahami.

\section{DAFTAR PUSTAKA}

Augustine, Charles D' Smith (1992).Teaching Elementary School Mathematics. New York: Harper Collins Publisher.

Baroody. A.J. 1993. Problem Solving, Reasoning, and Communicating. New York: Macmillan Publishing.

Cai, Jinfa. 1996. Assesing Students' Mathematical Communication.Official Journal of the Science and Mathematics Volume 96 No 5 Mei 1996. Hal: 238-246.

Crowley, M.L.(1987). The Van hiele Model of the Development of Geometric Thought. Dalam Lindquist, M.M and Shulte, A.P. (Eds.), Learning and Teaching Geometry, K12, (pp. 1-16). Reston VA: National Council of Teachers of Mathematics.

De Porter, B.\& Hernacki, M. (1999). Quantum learning: Membiasakan belajar nyaman dan menyamankan. (Penerjemah Alwiyah Abdurrahman). Bandung: Kaifa

Greenes, C. dan Schulman, L. 1996.Communication Processes in Mathematical Explorations and Investigation. Dalam Elliott, P. C. dan Kenney, M. J., Communication in Mathematics, K-12 and Beyond. Virginia: NCTM.

Hudoyo.H. (1998).Pembelajaran Matematika Menurut Pandangan Konstruktivistik. Makalah Seminar Nasional Pendidikan Matematika, IKIP Malang.

Kahfi, M. Sohibul. 1999. Pandangan Konstruktifisme dalam Pembelajaran Matematika.Malang: Jurusan Matematika FMIPA UM

Kennedy,L.M. Tipps Steve. (1994). Guiding Children's Learning of Mathematics.Wadswarsh Publishing Company.

Moleong, Lexy J. 2011. Metodologi Penelitian Kualitatif. Rosda: Bandung

Mulyati, Sri. 2000. Geometri Euclid. Malang: FMIPA UM

National Council of Teachers of Mathematics.2000a. Principles and Standards for School Mathematics. NCTM: Reston VA.

National Council of Teachers of Mathematics.2000b. learning Mathematics for A New Century.2000 Yearbook NCTM: Reston VA.

NCTM (2000). Principles and Standards for School Mathematics, Reston, Virginia. Patricia. C. Alcaro, dkk. 2000. Fractions Attack! Children Thinking and Talking Mathematically. Teaching Children Mathematics Vol 6 No 9 Mei 2000. Hal: 562- 567

Sumarmo (2006). Berfikir Matematik Tingkat Tinggi. Makalah pada Seminar Pendidikan Matematika UNPAD, Bandung.

Sumarmo, U. 2008. Berfikir Matematik: Apa, Mengapa, dan Bagaimana Cara Mempelajarinya. Disampaikan pada Kuliah Umum Program Studi $\begin{array}{lllll}\text { MatematikaUniversitas } & \text { Islam } & \text { Bandung, } & 27 & \text { Mei }\end{array}$ 
CENDEKIA, Vol. 9, No. 2, Oktober 2015

p ISSN: 1978 2098; e ISSN: 2407 8557; Web: cendekia.pusatbahasa.or.id

Pusat Kajian Bahasa dan Budaya, Surakarta, Indonesia

Utomo H. Fajar, Wardhani, S. Indah \& Asrori, RA Mohammad. 2015. Komunikasi Matematika

Berdasarkan Teori van Hiele pada Mata Kuliah Geometri Ditinjau dari Gaya Belajar Mahasiswa Program Studi Pendidikan Matermatika. Cendekia, 9(2): 159 170. 